\title{
Glu298Asp polymorphism in the NOS3 gene is not associated with susceptibility to chronic heart failure in a Russian population
}

\author{
E.S. Goppe ${ }^{1}$, P.E. Maltese ${ }^{2}$, A. Chernova ${ }^{3}$, S.Y. Nikulina ${ }^{1}$, \\ A. Semenchukov ${ }^{3}$, A. Matveeva ${ }^{1}$, E. Manara $^{4}$ and M. Bertelli ${ }^{4}$ \\ ${ }^{1}$ Department of Internal Diseases 1, Krasnoyarsk State Medical University, \\ Krasnoyarsk, Russia \\ ${ }^{2}$ Magi's Lab, Rovereto, Italy \\ ${ }^{3}$ Russia-Italy Laboratory of Medical Genetics MAGI-Russia, Research \\ Institute for Molecular Medicine \& Pathobiochemistry, Krasnoyarsk State \\ Medical University V.F. Voino-Yasenetsky, Krasnoyarsk, Russia \\ ${ }^{4}$ MAGI Euregio, Bolzano, Italy \\ Corresponding author: E. Manara \\ E-mail: elena.manara@assomagi.org
}

Genet. Mol. Res. 18 (1): gmr18143

Received September 11, 2018

Accepted January 25, 2019

Published January 31, 2019

DOI http://dx.doi.org/10.4238/gmr18143

\begin{abstract}
The eNOS Glu298Asp (rs1799983) polymorphism of the NOS3 gene has been implicated as a risk factor for cardiovascular diseases; however, not all studies find significant associations. We examined this possibility in a Russian (Siberian) population. One hundred patients with chronic heart failure and 40 controls were investigated. PCR analysis was performed on DNA samples. The aim was to evaluate a possible association between the (Glu298Asp) polymorphism (rs1799983) of the NOS3 gene and susceptibility to chronic heart failure in the Russian population. We evaluated genotype distributions in patient and control groups and assessed the relationship between genotypes and chronic heart failure. We found that this polymorphism is not associated with increased risk of chronic heart failure in our study cohort. In conclusion, testing of the NOS3 gene polymorphism does not seem useful for evaluating predisposition for chronic heart failure or its diagnosis and prognosis.
\end{abstract}

Key words: polymorphism; chronic heart failure; genotype; Glu298Asp; NOS3 gene 


\section{INTRODUCTION}

Chronic low heart performance leads to chronic heart failure (CHF), a syndrome with typical symptoms (shortness of breath, swelling of ankles, fatigue) and signs (elevated jugular vein pressure, lung rales, peripheral edema) caused by disruption of heart structure and/or function, reduced cardiac output and/or increased intra-cardiac pressure at rest or during exercise. This complex syndrome is a significant health care issue with high incidence and mortality. Prevalence is estimated at more than 10 million patients in Europe and 23 million worldwide (Jessup and Brozena, 2003). More than 612,000 persons per year are diagnosed for the first time with heart failure in Russia. One in every eight death certificates mentions heart failure, with $12 \%$ as the primary cause of death (usually coronary heart disease, heart attacks, high blood pressure).

These figures indicate that substantial efforts are needed to identify and treat factors that predispose to CHF to reduce the risk of heart failure by preventing its occurrence, and to obtain better overall survival. Research into polymorphisms identifying patients at risk of heart failure could be a useful contribution to this effort (Mosterd and Hoes, 2007).

Genetic polymorphisms in genes belonging to pathways involved in the regulation of basal vascular tone and cardiac myocyte function have been the focus of many studies designed to unravel the contribution of germline genetics in patients with heart failure.

The endothelial synthase of the nitric oxide gene, also known as the nitric oxide synthase 3 (NOS3) gene, encodes the enzyme that converts L-arginine to nitric oxide (NO). It is expressed in the early stages of cardio-genesis and plays an essential role in normal heart development. Nitric oxide is a small gaseous lipophilic molecule involved in various biological processes important for the cardiovascular system, such as regulation of the smooth muscle tone of blood vessels and platelet aggregation in the clotting process. Nitric oxide causes vasodilation, prevents migration and proliferation of vascular smooth muscle cells, and inhibits adhesion of platelets and leucocytes (Yang et al., 1993; Jeremy et al., 1999).

The NOS3 gene contains 26 exons spanning $21 \mathrm{~kb}$ on chromosome 7q35-36 (Marsden et al., 1993). Various polymorphisms in the NOS3 gene have been reported. A common polymorphism is the Glu298Asp substitution in the eNOS enzyme, whose functions are still unclear. The polymorphism does not change the kinetics of the reaction leading to the production of NO, although eNOS Asp298 has been found more susceptible to proteolytic cleavage than eNOS Glu298, and subjects with the Asp298 variant may show a reduction in nitric oxide production ( Tesauro et al., 2000; Leeson et al., 2002). The eNOS Glu298Asp (rs1799983) polymorphism has been implicated as a risk factor for various cardiovascular diseases, such as congenital heart defects ( Shaw et al., 2005; Van Beynum et al., 2008; Khatami et al., 2017), coronary artery disease (Colombo et al., 2003; Shahid and Rehman, 2017), myocardial infarction (Hibi et al., 1998), hypertension (Miyamoto et al., 1998; Gamil et al., 2017) and heart failure (Velloso et al., 2010). However, other authors report contradictory results (Kato et al., 1999; Nassar et al., 2001; Gamil et al., 2017). This could be due to sample size and/or cohort ethnicity.

It is of utmost diagnostic, preventive and therapeutic importance to understand the molecular events that trigger the development and progression of heart failure in different populations. The aim of this paper was to investigate the relationship between the 
Glu298Asp polymorphism (rs1799983) in endothelial nitric oxide synthase and the risk of developing chronic heart failure in a Russian population.

\section{MATERIAL AND METHODS}

\section{Patients and healthy subjects}

One hundred patients with chronic heart failure of varying severity confirmed clinically and by other investigations, were enrolled in the study in the period March 2016 to April 2017 at Krasnoyarsk Interdistrict Hospital no. 20. The study was approved by and performed in accordance with the protocol of the institutional ethics committee. The study inclusion criteria were: a history of CHF; either gender; any age; informed consent; resident in Krasnoyarsk; ability to perform the necessary procedure. Patients were assessed for overall health status, undergoing palpation, percussion, auscultation, electrocardiography and echocardiography, as indicated by the European Society of Cardiology (Ponikowski et al., 2016). Briefly, we estimated probability of CHF based only on medical history (e.g. coronary heart disease, hypertension, use of diuretics), symptoms (e.g. shortness of breath, bilateral edema, increased jugular vein pressure, apical impulse displacement) and ECG (preserved ejection fraction of left ventricle $>50 \%$; low ejection fraction of left ventricle $<40 \%$; average ejection fraction of left ventricle 40-49\%). The control group consisted of 40 subjects without CHF. A blood sample for molecular genetic studies was collected during assessment. Development of research protocols and genetic analysis were conducted in the MAGI genetic laboratory in Italy and in the Russian-Italian laboratory of medical genetics in Krasnoyarsk.

\section{Polymerase chain reaction (PCR)-restriction fragment length screening for the NOS3 rs1799983 polymorphism}

DNA was extracted from $0.5 \mathrm{~mL}$ whole blood with E. Z. N. A. DNA blood kits (omega Bio-Tek; NORCROSS, GA, USA), as previously described (Akhmedova et al., 2017).

Screening for the p.(Glu298Asp) polymorphism in the NOS3 gene was performed by PCR amplification of $100 \mathrm{ng}$ of DNA, followed by ECO24I restriction and fragment length screening. The PCR amplification of a $153 \mathrm{bp}$ fragment encompassing the polymorphism rs1799983 (NM_000603.4:c.894T>G) was performed using AmpliTaq Gold fast (Thermoscientific, Milan, Italy) and 10pmol primers 5'GGCTGGACCCCAG GAAAC3' (forward) and 5'CCACCCAGTCAATCCCTTTG3" (reverse) as follows: $95^{\circ} \mathrm{C}$ for $10 \mathrm{~min}$ (initial denaturation), then 35 cycles of $95^{\circ} \mathrm{C}$ for $30 \mathrm{~s}$ (denaturation), $57^{\circ} \mathrm{C}$ for 30 $\mathrm{s}$ (annealing) and $72^{\circ} \mathrm{C}$ for $30 \mathrm{~s}$ (extension), then final elongation at $72^{\circ} \mathrm{C}$ for $5 \mathrm{~min}$. The restriction reaction was performed on the amplified fragment using the enzyme ECO24I (Thermoscientific, Milan, Italy) at $37^{\circ} \mathrm{C}$ for $100 \mathrm{~min}$, followed by enzyme inactivation for $20 \mathrm{~min}$ at $65^{\circ} \mathrm{C}$. Digestion was resolved on a $2 \%$ agarose gel and detected by ultraviolet radiation. The $153 \mathrm{bp}$ fragment was cleaved into 88 and $65 \mathrm{bp}$ fragments in the presence of a $\mathrm{T}$ at nucleotide 954 of the NOS3 gene. 


\section{Statistical analysis}

Deviation from Hardy-Weinberg equilibrium was tested in the control group using an online tool (the Hardy-Weinberg 2-Allele Calculator http://www.had2know.com/academics/hardy-weinberg-equilibrium-calculator-2-alleles.html).

We used the chi-square $\left(\chi^{2}\right)$ test to evaluate the distribution of polymorphic NOS3 rs1799983 in patients and controls. $\chi^{2}$ was calculated using the Cochran-Armitage test for trend. Armitage's trend test is a valid test even in Hardy-Weinberg disequilibrium (Armitage, 1955).

The odds ratio was used to assess the risk of an association between the polymorphism and chronic heart failure. Statistical analysis was conducted with MedCalc software (Mariakerke, Belgium). Statistical significance was set at $\mathrm{P}$ value $<0.05$.

\section{RESULTS}

\section{Analysis of the NOS3 Glu298Asp polymorphism}

We compared the alleles and frequencies of rs1799983 NOS3 Glu298Asp genotypes in $100 \mathrm{CHF}$ patients and 40 controls. Our group of patients included 57 men and 43 women, with an average age of $68 \pm 11.5$ years.

The results of restriction enzyme digestion for analysis of the rs1799983 polymorphism of the NOS3 gene revealed that five of our cohort of CHF patients were homozygous for the $\mathrm{T}$ nucleotide, 48 were homozygous for the $\mathrm{G}$ variant and 47 patients were heterozygous. The frequencies of the $\mathrm{T}, \mathrm{G}$ and $\mathrm{T} / \mathrm{G}$ variants in the control group were $5 \%, 60 \%$ and $35 \%$, respectively. The genotype frequencies of rs1799983 were in HardyWeinberg equilibrium in the $\mathrm{CHF}$ cohort $(\mathrm{P}=0.16)$, but they deviated significantly from that equilibrium in the control group $(\mathrm{P}=0.04)$.

There was no significant difference in the genotype distribution between patients and controls $(\mathrm{P}=0.23$ considering $\mathrm{G} / \mathrm{G}, \mathrm{G} / \mathrm{T}$ and $\mathrm{T} / \mathrm{T}$ groups and $\mathrm{P}=0.071$, considering the dominant genetic model G/G vs G/T +T/T) (Table 1).

Table 1. rs1799983 NOS3 Glu298Asp allele and genotype frequencies recorded in chronic heart failure patients and controls.

\begin{tabular}{lcccccccc}
\hline $\begin{array}{l}\text { Genotype } \\
\text { (codon change) }\end{array}$ & Patients (N=100) & Controls (N=40) & $\chi^{2}$ for trend & P value & OR & 95\% CI & Significance level \\
\hline G/G (Glu/Glu) & $48(48 \%)$ & $14(35 \%)$ & & & Reference & - & - \\
G/T (Glu/Asp) & $47(47 \%)$ & $24(60 \%)$ & 1.426 & $\mathrm{P}=0.2324$ & 1.7508 & 0.8089 to 3.7894 & $\mathrm{P}=0.1551$ \\
T/T (Asp/Asp) & $5(5 \%)$ & $2(5 \%)$ & & & 1.3714 & 0.2396 to 7.8494 & $\mathrm{P}=0.7227$ \\
\hline Dominant model & & & $\chi^{2}$ & P value & OR & 95\% CI & Significance level \\
\hline G/G Vs G/T + T/T & $52(52 \%)$ & $26(65 \%)$ & 3.254 & $\mathrm{P}=0.0712$ & 1.7143 & 0.8025 to 3.6619 & $\mathrm{P}=0.1640$ \\
\hline
\end{tabular}

\section{Demographic and clinical characteristics of the cohort of patients divided by genotype}

Table 2 shows the main clinical characteristics of the CHF group divided by genotype. Clinical and laboratory values were compared between different genotypes with a polymorphic NOS3 298 codon; however, no significant differences were noted in the case of wall ischemia $(\mathrm{P}=0.28)$, palpitations $(\mathrm{P}=0.67)$, arrhythmia $(\mathrm{P}=0.98)$, myocarditis 
$(\mathrm{P}=0.94)$, cardiomyopathy $(\mathrm{P}=0.58)$, hypertensive disease $(\mathrm{P}=0.58)$, valve disease $(\mathrm{P}=0.71)$ or post-infarction cardiosclerosis $(\mathrm{P}=0.34)$ (Table 2).

\begin{tabular}{|c|c|c|c|c|c|c|}
\hline \multirow[t]{2}{*}{$\begin{array}{l}\text { NOS3 } \\
\text { p.(Glu298Asp) }\end{array}$} & \multicolumn{3}{|c|}{ Wall ischemia } & \multicolumn{3}{|c|}{ Palpitations } \\
\hline & $\mathrm{NO}$ & YES & $\chi^{2}$ (p value) & $\mathrm{NO}$ & YES & $\chi^{2}$ (p value) \\
\hline Glu/Glu & $40(50.0 \%)$ & $4(33.3 \%)$ & & $26(45.6 \%)$ & $17(47.2 \%)$ & \\
\hline Glu/Asp & $35(43.8 \%)$ & $8(66.7 \%)$ & $\chi^{2}=2.529$ & $2747.4 \%)$ & $18(50.0 \%)$ & $\chi^{2}=0.782$ \\
\hline Asp/Asp & $5(6.3 \%)$ & 0 & $\mathrm{P}=0.28$ & $4(7.0 \%)$ & $1(2.8 \%)$ & $\mathrm{P}=0.67$ \\
\hline \multirow[t]{2}{*}{ TOTAL } & 80 & 12 & & 57 & 36 & \\
\hline & \multicolumn{3}{|c|}{ Arrhythmia } & \multicolumn{3}{|c|}{ Myocarditis } \\
\hline Glu/Glu & $\begin{array}{c}\text { NO } \\
19(47.5 \%)\end{array}$ & $\begin{array}{c}\text { YES } \\
25(46.3 \%)\end{array}$ & $\chi^{2}$ (p value) & $\begin{array}{c}\mathrm{NO} \\
43(46.7 \%)\end{array}$ & YES & $\chi^{2}$ (p value) \\
\hline $\begin{array}{l}\text { Glu/Giu } \\
\text { Glu/Asp }\end{array}$ & $\begin{array}{l}19(4.5 \%) \\
19(47.5 \%)\end{array}$ & $\begin{array}{l}25(40.3 \%) \\
26(48.1 \%)\end{array}$ & $\chi^{2}=0.022$ & $\begin{array}{l}43(40.1 \%) \\
44(47.8 \%)\end{array}$ & $\begin{array}{l}1(50.0 \%) \\
1(50.0 \%)\end{array}$ & $\chi^{2}=0.115$ \\
\hline Asp/Asp & $2(5.0 \%)$ & $3(5.6 \%)$ & $\mathrm{P}=0.98$ & $5(5.4 \%)$ & 0 & $\mathrm{P}=0.94$ \\
\hline \multirow[t]{2}{*}{ TOTAL } & 40 & 54 & & 92 & 2 & \\
\hline & \multicolumn{3}{|c|}{ Cardiomyopathy } & \multicolumn{3}{|c|}{ Hypertensive disease } \\
\hline Glu/Glu & $\begin{array}{c}\mathrm{NO} \\
16(44.4 \%)\end{array}$ & $\begin{array}{c}\text { YES } \\
28(483 \%)\end{array}$ & $\chi^{2}$ (p value) & $\begin{array}{c}\mathrm{NO} \\
4(33,3 \%)\end{array}$ & $\begin{array}{c}\text { YES } \\
40(48.8 \%)\end{array}$ & $\chi^{2}$ (p value) \\
\hline Glu/Asp & $19(52.8 \%)$ & $26(44.8 \%)$ & $\chi^{2}=1.071$ & $7(58.3 \%)$ & $38(46.3 \%)$ & $\chi^{2}=1.083$ \\
\hline Asp/Asp & $1(2.8 \%)$ & $4(6.9 \%)$ & $\mathrm{P}=0.58$ & $1(8.3 \%)$ & $4(4.9 \%)$ & $\mathrm{P}=0.58$ \\
\hline \multirow[t]{2}{*}{ TOTAL } & 36 & 58 & & 12 & 82 & \\
\hline & & Valve disease & & \multicolumn{3}{|c|}{ Postinfarction cardiosclerosis } \\
\hline Glu/Glu & $\begin{array}{c}\mathrm{NO} \\
38(48.7 \%)\end{array}$ & $\begin{array}{c}\text { YES } \\
6(37.5 \%)\end{array}$ & $\chi^{2}$ (p value) & $\begin{array}{c}\mathrm{NO} \\
13(44.4 \%)\end{array}$ & $\begin{array}{c}\text { YES } \\
31(52.5 \%)\end{array}$ & $\chi^{2}(\mathrm{p}$ value $)$ \\
\hline Glu/Asp & $36(46.2 \%)$ & $9(56.3 \%)$ & $\chi^{2}=0.671$ & $20(52.8 \%)$ & $25(42.4 \%)$ & $\chi^{2}=2.13$ \\
\hline Asp/Asp & $4(5.1 \%)$ & $1(6.3 \%)$ & $\mathrm{P}=0.71$ & $2(2.8 \%)$ & $3(5.1 \%)$ & $\stackrel{\tilde{P}}{\mathrm{P}}=0.34$ \\
\hline TOTAL & 78 & 16 & & 35 & 59 & \\
\hline
\end{tabular}

\section{DISCUSSION}

Chronic heart failure is a significant worldwide health care issue, and it is of utmost importance to understand the molecular events involved in this chronic disease that in most cases leads to death. We investigated the Glu298Asp polymorphism in endothelial nitric oxide synthase in relation to CHF risk.

Contradictory results have been obtained in other studies on a possible correlation between the eNOS Glu298Asp polymorphism and heart disease (Hibi et al., 1998; Miyamoto et al., 1998; Kato et al., 1999; Nassar et al., 2001; Colombo et al., 2003; Shaw et al., 2005; van Beynum et al., 2008; Velloso et al., 2010; Gamil et al., 2017; Khatami et al., 2017; Shahid and Rehman, 2017). This may depend on group selection, due to variable distribution of the polymorphism in different ethnic groups, and small sample size (Chen et al., 2001; Rosas-Vargas et al., 2003; Sandrim et al., 2006). The Glu allele has been reported to have different allelic frequencies: $74 \%$ in the USA (Fatini et al., 2004), 99\% in Japan (Kato et al., 1999), 99\% in Korea (Park et al., 2004), 88\% in Mexico (Stephens et al., 1996), 85\% in Chile (Jaramillo et al., 2006), 83\% in Turkey (Cam et al., 2005) and 67\% in Brazil (Velloso et al., 2010). We therefore evaluated the role of this polymorphism in CHF in a Russian population. To the best of our knowledge, this is the first study performed on a Siberian population. The result of this preliminary study conducted on a relatively small cohort showed relatively low Glu298 allele frequencies of 65 and $71.5 \%$ in our control group and patient cohort, respectively.

, The rs1799983 NOS3 polymorphism was not found to be associated with CHF in our population. No significant differences were found when we compared clinical characteristics (i.e. wall ischemia, palpitations, arrhythmia, myocarditis, cardiomyopathy, hypertensive disease, valve disease, post-infarction cardiosclerosis) in groups with different 
genotypes. Because of gender differences in NO production (Forte et al., 1998; Tsang et al., 2001), the allele and genotype frequencies of the polymorphism were analyzed separately in men and women. No differences were found (data not shown).

In our study, we observed Hardy-Weinberg disequilibrium in rs1799983 in controls. This has also been described by others (Tang et al., 2008; Serrano et al., 2010; Li et al., 2011). The Hardy-Weinberg model requires several assumptions, such as unlimited population size and that natural selection does not act on the alleles under consideration. However, in a previous study on this polymorphism, it was suggested that Hardy-Weinberg disequilibrium was caused by selection pressure (Dhangadamajhi et al., 2009).

In conclusion, our results show that genetic testing of polymorphism rs1799983 cannot be used to assess risk for CHF in routine screening and did not provide useful clinical information for disease prognosis in our Russian population. Limitations of our study include the small size of the patient and control groups. Larger cohorts of controls and CHF patients are needed to confirm that eNOS Glu298Asp does not play a role in CHF in the Siberian population.

\section{CONFLICT OF INTEREST}

The authors declare that they do not have any conflicts of interest.

\section{ACKNOWLEDGMENTS}

We would like to thank Dr Helen Ampt for revising the manuscript and the Provincia Autonoma di Bolzano that participated in the funding of this project (n. 116/2016).

\section{REFERENCES}

Akhmedova E, Nikulina SY, Salmina AB, Chernova A, et al. (2017). AluYb8 insertion in the WNK1 gene is not associated with hypertension in a Russian caucasian population. Genet. Mol. Res. 16: gmr16039809.

Armitage P. (1955). Tests for Linear Trends in Proportions and Frequencies. Biometrics 11: 375-386.

van Beynum IM, Mooij C, Kapusta L, Heil S, et al. (2008). Common 894G\&gt;T single nucleotide polymorphism in the gene coding for endothelial nitric oxide synthase (eNOS) and risk of congenital heart defects. Clin. Chem. Lab. Med. 46: 1369-1375.

Cam SF, Sekuri C, Tengiz I, Ercan E, et al. (2005). The G894T polymorphism on endothelial nitric oxide synthase gene is associated with premature coronary artery disease in a Turkish population. Thromb. Res. 116: 287-292.

Chen W, Srinivasan SR, Elkasabany A, Ellsworth DL, et al. (2001). Combined effects of endothelial nitric oxide synthase gene polymorphism (G894T) and insulin resistance status on blood pressure and familial risk of hypertension in young adults: The Bogalusa heart study. Am. J. Hypertens. 14: 1046-1052.

Colombo MG, Paradossi U, Andreassi MG, Botto N, et al. (2003). Endothelial nitric oxide synthase gene polymorphisms and risk of coronary artery disease. Clin. Chem. 49: 389-395.

Dhangadamajhi G, Mohapatra BN, Kar SK, and Ranjit M. (2009). Endothelial nitric oxide synthase gene polymorphisms and Plasmodium falciparum infection in indian adults. Infect. Immun. 77: 2943-2947.

Fatini C, Sofi F, Sticchi E, Gensini F, et al. (2004). Influence of endothelial nitric oxide synthase gene polymorphisms (G894T, 4a4b, T-786C) and hyperhomocysteinemia on the predisposition to acute coronary syndromes. Am. Heart J. 147: 516-521.

Forte P, Kneale B.J, Milne E, Chowienczyk PJ, et al. (1998). Evidence for a difference in nitric oxide biosynthesis between healthy women and men. Hypertension 32: 730-734.

Gamil S, Erdmann J, Abdalrahman IB, and Mohamed AO. (2017). Association of NOS3 gene polymorphisms with essential hypertension in Sudanese patients: a case control study. BMC Med. Genet. 18: 128. 
Hibi K, Ishigami T, Tamura K, Mizushima S, et al. (1998). Endothelial nitric oxide synthase gene polymorphism and acute myocardial infarction. Hypertension 32: 521-526.

Jaramillo PC, Muñoz MA, Lanas MC, Lanas ZF, et al. (2006). Endothelial nitric oxide synthase G894T gene polymorphism in Chilean subjects with coronary artery disease and controls. Clin. Chim. Acta 371: 102-106.

Jeremy JY, Rowe D, Emsley AM, and Newby, A.C. (1999). Nitric oxide and the proliferation of vascular smooth muscle cells. Cardiovasc. Res. 43: 580-594.

Jessup M, and Brozena S. (2003). Heart failure. N. Engl. J. Med. 348: 2007-18.

Kato N, Sugiyama T, Morita H, Nabika T, et al. (1999). Lack of evidence for association between the endothelial nitric oxide synthase gene and hypertension. Hypertension 33: 933-936.

Khatami M, Ratki FM, Tajfar S, and Akrami F. (2017). Relationship of the MTHFD1 (rs2236225), eNOS (rs1799983), CBS (rs2850144) and ACE (rs4343) gene polymorphisms in a population of Iranian pediatric patients with congenital heart defects. Kaohsiung J. Med. Sci. 33: 442-448.

Leeson CPM, Hingorani AD, Mullen MJ, Jeerooburkhan N, et al. (2002). Glu298Asp endothelial nitric oxide synthase gene polymorphism interacts with environmental and dietary factors to influence endothelial function. Circ. Res. 90: $1153-1158$.

Li J, Cun Y, Tang WR, Wang Y, et al. (2011). Association of eNOS gene polymorphisms with essential hypertension in the Han population in southwestern China. Genet. Mol. Res. 10: 2202-2212.

Marsden PA, Heng HH, Scherer SW, Stewart RJ, et al. (1993). Structure and chromosomal localization of the human constitutive endothelial nitric oxide synthase gene. J. Biol. Chem. 268: 17478-17488.

Miyamoto Y, Saito Y, Kajiyama N, Yoshimura M, et al. (1998). Endothelial nitric oxide synthase gene is positively associated with essential hypertension. Hypertension 32: 3-8.

Mosterd A, and Hoes AW. (2007). Clinical epidemiology of heart failure. Heart 93: 1137-1146.

Nassar BA, Bevin LD, Johnstone DE, O’Neill BJ, et al. (2001). Relationship of the Glu298Asp polymorphism of the endothelial nitric oxide synthase gene and early-onset coronary artery disease. Am. Heart J. 142: 586-589.

Park K-W, You K-H, Oh S, Chae I-H, et al. (2004). Association of endothelial constitutive nitric oxide synthase gene polymorphism with acute coronary syndrome in Koreans. Heart 90: 282-285.

Ponikowski P, Voors AA, Anker SD, Bueno H, et al. (2016). 2016 ESC Guidelines for the diagnosis and treatment of acute and chronic heart failure. Eur. J. Heart Fail. 18: 891-975.

Rosas-Vargas H, Flores-Segura A, Guizada-Claure B, Vargas-Alarcón G, et al. (2003). Endothelial nitric oxide synthase gene polymorphism in the Indian and Mestizo populations of Mexico. Hum. Biol. 75: 91-96.

Sandrim VC, Coelho EB, Nobre F, Arado GM, et al. (2006). Susceptible and protective eNOS haplotypes in hypertensive black and white subjects. Atherosclerosis 186: 428-432.

Serrano NC, Díaz LA, Casas JP, Hingorani AD, et al. (2010). Frequency of eNOS polymorphisms in the Colombian general population. BMC Genet. 11: 54

Shahid SU, and Rehman A. (2017). Association Patterns of Endothelial Nitric Oxide Synthase Gene ( NOS3 ) Variant Glu298Asp with Blood Pressure and Serum Lipid Levels in Subjects with Coronary Artery Disease from Pakistan. Ann. Hum. Genet. 81: 129-134.

Shaw GM, Iovannisci DM, Yang W, Finnell RH, et al. (2005). Risks of human conotruncal heart defects associated with 32 single nucleotide polymorphisms of selected cardiovascular disease-related genes. Am. J. Med. Genet. A 138: 21-26.

Stephens NG, Parsons A, Schofield PM, Kelly F, et al. (1996). Randomised controlled trial of vitamin E in patients with coronary disease: Cambridge Heart Antioxidant Study (CHAOS). Lancet 347: 781-786.

Tang W, Yang Y, Wang B, and Xiao C. (2008). Association between a G894T Polymorphism of eNOS Gene and Essential Hypertension in Hani and Yi Minority Groups of China. Arch. Med. Res. 39: 222-225.

Tesauro M, Thompson WC, Rogliani P, Qi L, et al. (2000). Intracellular processing of endothelial nitric oxide synthase isoforms associated with differences in severity of cardiopulmonary diseases: cleavage of proteins with aspartate vs. glutamate at position 298. Proc. Natl. Acad. Sci. U. S. A. 97: 2832-2835.

Tsang KW, Ip SK, Leung R, Tipoe GL, et al. (2001). Exhaled Nitric Oxide: The Effects of Age, Gender and Body Size. Lung 179: 83-91.

Velloso MWM, Pereira SB, Gouveia L, Chermont S, et al. (2010). Endothelial nitric oxide synthase Glu298Asp gene polymorphism in a multi-ethnical population with heart failure and controls. Nitric Oxide 22: 220-225.

Yang Z, Arnet U, Bauer E, Von Segesser L, et al. (1993). Thrombin-Induced Endothelium-Dependent Inhibition and Direct Activation of Platelet-Vessel Wall Interaction. Circulation 89: 2266-2273. 